\title{
EVI2 INDEX TREND APPLIED TO THE VEGETATION OF THE STATE OF RIO DE JANEIRO BASED ON NON-PARAMETRIC TESTS AND MARKOV CHAIN
}

\author{
TENDÊNCIA DO EVI2 APLICADO NA VEGETAÇÃO DO ESTADO DO RIO DE \\ JANEIRO BASEADO EM TESTES NÃO-PARAMÉTRICOS E CADEIA DE MARKOV
}

\author{
Givanildo de GOIS ${ }^{1}$; Rafael Coll DELGADO ${ }^{1}$; José Francisco OLIVEIRA-JUNIOR ${ }^{1}$; \\ Thais Cristina de Oliveira SOUZA'; Paulo Eduardo TEODORO
}

1. Instituto de Floresta, Universidade Federal Rural do Rio de Janeiro - UFRRJ, Seropédica, RJ, Brasil; 2. Departamento de Biologia Geral, Universidade Federal de Viçosa, Viçosa, MG, Brasil. eduteodoro@ hotmail.com

\begin{abstract}
The study aimed to assess the growth and decrease in vegetation trend by Enhanced Vegetation Index (EVI2) through the application of statistical tests and Markov's chain in the state of Rio de Janeiro (SRJ). Monthly data from EVI2 were calculated for the vegetations of the State of Rio de Janeiro (SRJ) from 2001 to 2012. Mann-Kendall (MK), Pettitt (P) and Estimator of Curvature Slope Sen (Se) tests assessed EVI2 trend, while the future scenarios were evaluated by Markov chain. Overall, there is an insignificant trend in vegetation growth in $75 \%$, followed by a significant trend of decreasing in $25 \%$ of the regions. Pettitt's test showed that there is not significant (NS) abrupt changes, both growth and decreasing vegetation, and significant (S) abrupt changes of decreasing vegetation in the others Government regions. Spatial analysis from EVI2 in the regions Médio Paraíba amd Serrana showed the occurrence of NS abrupt change in the vegetation in November 2007 and 2003. Norte Fluminense and Metropolitana showed a NS vegetation increase in October 2003 and 2005. Noroeste Fluminense and Centro Sul Fluminense revealed an NS and S abrupt change of decreasing vegetation in April 2006. In Costa Verde and Baixadas Litorâneas NS and S abrupt changes in decreasing vegetation were observed in May 2004. Future scenarios showed changes in vegetation trend in SRJ with indication of decreasing. Predictions of changes in future scenarios ranging from 1 to 2 years in constant intervals (3 to 10 years) were observed in all future scenarios analyzed in the SRJ.
\end{abstract}

KEYWORDS: Orbital sensors. Statistical tests. Geotechnology. Markovian matix.

\section{INTRODUCTION}

Several government measures have been adopted in controlling vegetation, such as the establishment of Permanent Preservation Areas (PPA) and Conservation Units (CU) and, finally, monitoring of hot spots via satellite (CAÚLA et al., 2015). However, there is no rigorous control of Brazilian biomes in spatial scale, because biomes are constantly threatened by human activities such as farming, agriculture and real Estate occupation (ALEIXO et al., 2010). Given the need for evaluating the vegetation in large areas some vegetation indices were created the NDVI (Normalized Difference Vegetation Index) by Rouse et al. (1974) and EVI (Enhanced Vegetation Index) by Huete et al. (1997, 1999 and 2002), both widely used in several dynamic studies on the vegetation (ZHANG et al., 2009; DELGADO et al., 2015; GOULART et al., 2015).

Demarchi et al. (2011) comment that sensory and spatial techniques help in the land use and occupation planning of a region; delimitation of PPAs, legal reserves and UCs; and maintenance of water resources and other areas recognized by the legislation as important for maintaining the environmental activities. Based on this, studies on the land cover dynamics in fragmented landscapes requires application of practical and specific methods, such as vegetation survey via geoprocessing and historical surveys (RODRIGUES, 1997). In this context, the Remote Sensing (RS) has contributed significantly to the improvement and quality of information, especially the design of areas occupied by vegetation cover, whether natural or established by human activities (GOULART et al., 2015).

The application of mathematical and statistical tools in the dynamics of vegetation in forest areas is of great importance in the knowledge of growth and decreased vegetation. Markov's chain, called Markovian Memory, shows if the previous status are irrelevant for predicting the following status, since the current status to be known, trying mathematically to describe stochastic processes. Pedrosa et al. (2007) reinforce that the model does not ignore the past, but assumes that all past information is concentrated in the present system status .Teixeira et al. (2007) concluded that the Markovian analysis are like an effective tool in the future forest dynamics projection. In the State of Rio de Janeiro (SRJ), there are few studies on the vegetation dynamics, followed by the trend identification and prediction at the regional scale. Therefore, the study aimed to assess the growth and decrease in vegetation trend by EVI2 vegetation index through the application of statistical tests and Markov's chain in the state of Rio de Janeiro. 


\section{MATERIAL AND METHODS}

\section{Location and characterization of the study area}

SRJ is located in the Brazilian Southeast region, between the latitudes $20^{\circ} 45^{\prime} 54$ and $23^{\circ} 21^{\prime} 57^{\prime \prime} \mathrm{S}$ and the longitude $40^{\circ} 57^{\prime} 59^{\prime \prime}$ and $44^{\circ} 53^{\prime} 18^{\prime \prime} \mathrm{W}$, with an area of $43,696.054 \mathrm{~km}^{2}$. It is bordered by the State of Espírito Santo at Northeast (NE); North (N) and Northwest (NW) with the State of Minas Gerais;
Southwestern (SW) with the State of São Paulo; and with the Atlantic Ocean at South (S) and East (E). It has extensive coastline, approximately $635 \mathrm{~km}$ long. Currently, the State is divided geopolitically into 92 municipalitiesinserted in eight Government regions (Serrana, Norte Fluminense, Noroeste Fluminense, Metropolitana, Médio Paraíba, Baixadas Litorâneas, Costa Verde and Centro Sul Fluminense) (Figure 1).

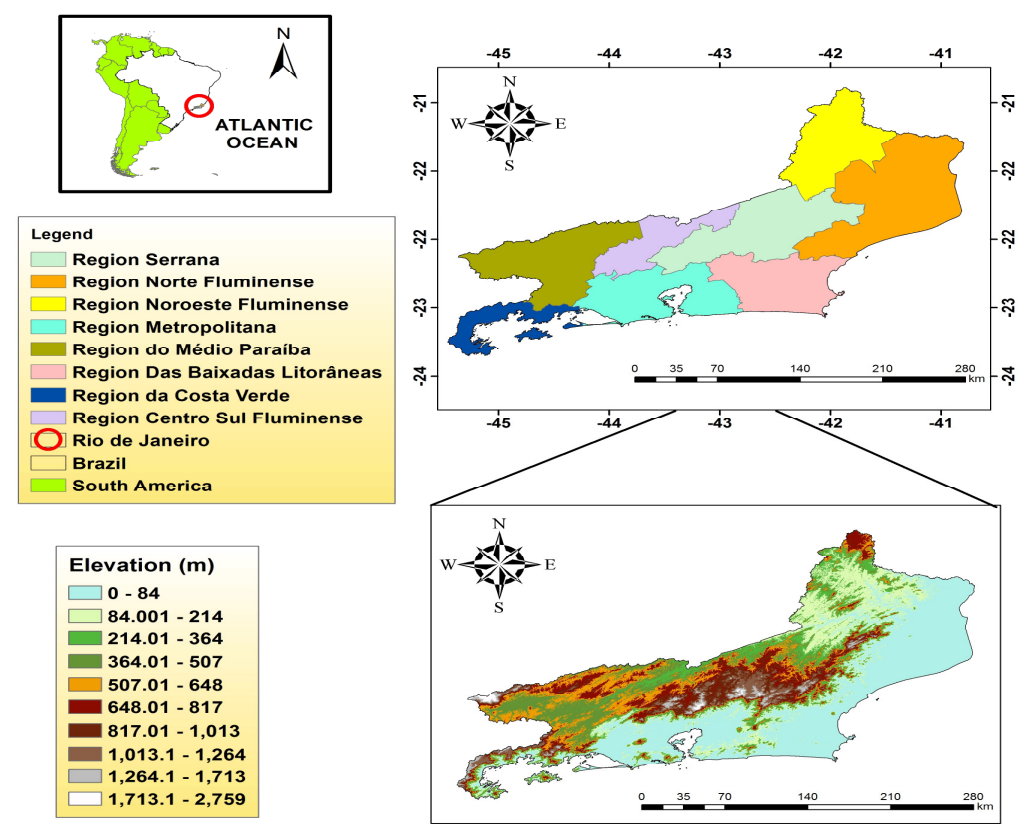

Figure 1. Geographical location and hypsometry (m) of the State of Rio de Janeiro in 2015.

Time series obtained from LAF-INPE of the Enhanced Vegetation Index 2 (2001-2012)

Monthly time series from 2001 to 2012 of vegetation data from the eight Government regions was used in the calculation of EVI2 index. EVI2 was proposed by Jiang et al. (2008) from LAF-INPE (Laboratory of Remote Sensing Applied to Agriculture and Forest of the National Institute of Space Research), available at: https://www.dsr.inpe.br/laf/series/index.php>. More information on the methodology is found in Freitas et al. (2011). LAF-INPE are in .csv format. Files were processed and organized vectorially for the eight Government regions of SRJ.

\section{Orbital data from Enhanced Vegetation Index 2 (2001-2012)}

In EVI2 spatial analysis was used pictures composed by 16 days (HUETE et al., 1999) from MODIS sensor on board the TERRA satellite via MOD13Q1 product (collection 5.0), with spatial resolution of $250 \mathrm{~m}$. Pictures were obtained from USGS - GLOVIS (United States Geological Survey - Global Visualization Viewer), available at: http://glovis.usgs.gov/. Based on USGS - GLOVIS platform, it were selected pictures wherein Pettit's test was significant for years and months for the eight Government regions to tiles H13V11 and H14V11, covering the SRJ. Subsequently, the data available in sinusoidal projection and HDF format were converted to the Geographic Coordinate System (GCS) projection and Geotiff format via Modis Reprojection Tool (MRT). This software enabled the union of H13V11 and H14V11 from MOD13Q1 product. EVI2 was calculated by the equation 1 :

$$
\mathrm{EVI} 2=2.5 \frac{\rho_{\mathrm{NIR}}-\rho_{\mathrm{RED}}}{\rho_{\mathrm{NIR}}+2.4 \rho_{\mathrm{RED}}+1}
$$

wherein, $\rho_{\mathrm{NIR}}$ is reflectance in the near infrared band and $\rho_{\mathrm{RED}}$ is reflectance in the red band.

\section{Statistical analysis}

Pettitt's test (1979) is a nonparametric test was used to identify the year of occurrence of abrupt change in EVI2 indices average. This test uses a version of the Mann-Whintney test, which verifies if two samples $X_{1}, \ldots, X_{t}$ and $X_{t+1}, \ldots, X_{T}$ belongs to the same population. 
For assessing the trend in time series of EVI2 index, it was applied the Mann-Kendall test (MK), according to Sneyers method (1975). The test considers the possibility of stability of a time series, the values succession occurs independently and the probability distribution should always remain the same (simple random series).

For estimating the magnitude of an EVI2 trend detected by MK test was used the median values of the Sen Curvature $\left(\mathrm{S}_{\mathrm{e}}\right)$ slope regarding the time series of EVI2. This procedure provides an estimated slope on a possible growth and vegetation contraction trend.

Through the transition matrix consisting the percentage slope values of Sen Curvature regarding the time series of EVI2 index obtained by the software environment $\mathrm{R}$ version 3.2.2 ( $\mathrm{R}$ DEVELOPMENT CORE TEAM, 2011), future scenarios of changes in the trend of vegetation at the scale of 1 to 10 years for the Government regions were simulated. It was established that there is vegetation growth trend (positive), but insignificant; or that have decreasing vegetation trend (negative) significant or insignificant in a multidirectional manner, i.e., portions of a class can theoretically change from a mutually exclusive category to another at any time. Therefore, the Markov chain can provide the likelihood of change increase or decrease in the vegetation, but can not present the spatial process of associated change dynamics (YANG et al., 2012).

\section{RESULTS AND DISCUSSION}

Insignificant records of vegetation growth trends $(Z>0$ and $p$-value $>0.05)$ based on EVI2 values were identified in the regions Médio Paraíba (0.0057), Serrana (0.0475), Norte Fluminense (0.0291) and Metropolitana (0.0311) with $\mathrm{S}_{\mathrm{e}}$ from 0.00002 to 0.00014 per year (Table 1). Insignificant decreasing vegetation trends $(Z<0$ and $p$-value $>0.05)$ were identified in the regions Norte Fluminense and Costa Verde with $S_{\mathrm{e}}$ from -0.00034 to -0.00019 per year. Significant decreasing vegetation trends $(\mathrm{Z}<0$ and $\mathrm{p}$-value $<0.05)$ were recorded in the regions Baixadas Litorâneas $(-0.1290)$ and Centro Sul Fluminense (-0.1600) with magnitude of $\mathrm{S}_{\mathrm{e}}$ from -0.00029 to -0.00050 per year.

Table 1. Statistical analysis of the trend e detection of years and months with abrupt changes in the values of EVI2 index, by non-parametric tests Mann-Kendall (MK), Sen method $\left(S_{e}\right)$ and Pettitt $(P)$ from 20012012.

\begin{tabular}{lcccccc}
\hline Regions & Score of $Z$ & MK & P-value & $\mathrm{S}_{\mathrm{e}}$ & Pettitt & Montly \\
\hline Médio Paraíba & 0.102 & 0.0057 & 0.920 & 0.00002 & $2007 \mathrm{NS}$ & November \\
Serrana & 0.845 & 0.0475 & 0.399 & 0.00014 & $2003 \mathrm{NS}$ & November \\
Norte Fluminense & 0.518 & 0.0291 & 0.606 & 0.00010 & $2003 \mathrm{NS}$ & October \\
Metropolitana & 0.553 & 0.0311 & 0.582 & 0.00005 & $2005 \mathrm{NS}$ & October \\
Baixadas Litorâneas & -2.297 & -0.1290 & 0.022 & -0.00029 & $2011 \mathrm{~S}$ & May \\
Noroeste Fluminense & -1.772 & -0.0997 & 0.077 & -0.00034 & $2006 \mathrm{NS}$ & April \\
Costa Verde & -1.598 & -0.0899 & 0.110 & -0.00019 & $2004 \mathrm{NS}$ & May \\
Centro Sul Fluminense & -2.841 & -0.1600 & 0.005 & -0.00050 & $2006 \mathrm{~S}$ & April \\
\hline
\end{tabular}

NS: not significant for $\mathrm{p}$-value $>0.05$; S: significant for $\mathrm{p}$-value $<0.05$

Pettitt's test showed the existence of no significant abrupt changes (NS), both of growth and decreasing vegetation to $5 \%$ probability into six regions of SRJ (Table 1). The corresponding years and months were in 2003 (October and November), 2004 (May), 2005 (October), 2006 (April) and 2007 (November). Pettitt's test identified significant abrupt change (s) only of decreasing vegetation to $5 \%$ probability in two regions SRJ (Baixadas Litorâneas and Centro Sul Fluminense) in 2006 (April) and 2011 (May).

Thematic maps of EVI2 were generated based on the Pettitt's test. It enable to identify changes in vegetation into eight Government regions such as occurrence of water bodies, areas with growth and decreasing vegetation (without vegetation). In thematic maps, negative values of EVI2 indicate the presence of water bodies and positive values of EVI2 index indicate the presence of areas with vegetation (scale 0.4 to 0.8 ) and without vegetation or sparse or exposed soils (decrease) at scale 0.3 to 0.4 .

Spatial analysis of EVI2 in Médio Paraíba showed a NS vegetation growth in November 2007, at directions W-NW, S-SW and S-SE (Figure 2). Records of water bodies and areas without vegetation characterized by low EVI2 values were observed across the region, which may be related to variations in the phenological cycles of the region (FERNANDES et al., 2011). This shows the presence of vegetation in advanced succession stage of dominant tree individuals adapted to the local climate. The Serrana region showed an NS vegetation growth based on EVI2 index again in November, similar to region do Médio Paraíba, in 2003 at directions N-NW, N-NE and W-SW. However, low EVI2 values were observed in the SW and E-NW of the region, which indicates the existence of wetlands (water 


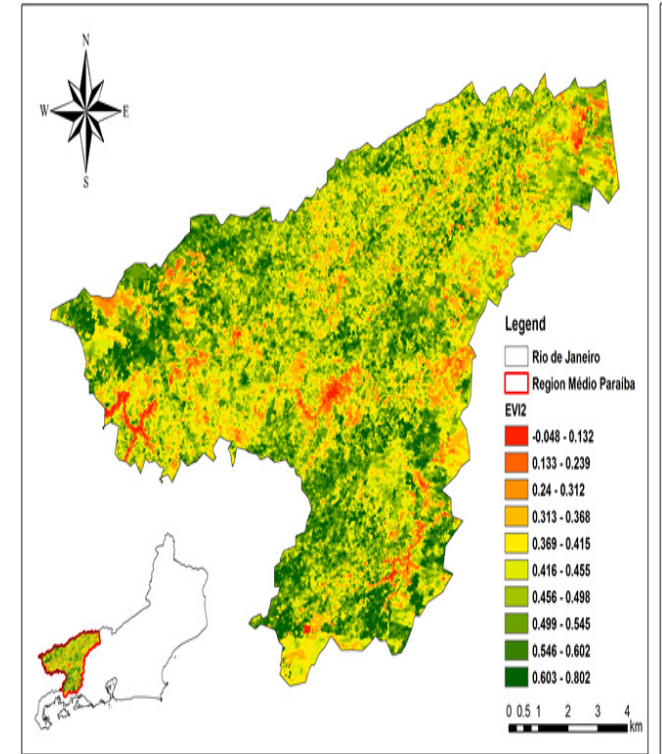

Figure 2. EVI2 indices in November 2003.

Serrana region is characterized by having serious constraints facing the urban occupation, given the slopes and complex topography (FERNANDES et al., 2011). Due to its physiography, much of the existing slopes in the region preserves the Atlantic Forest biome, such as the Parques Nacionais do Itatiaia (PNI), Serra da Bocaína, Serra dos Órgãos and Serra do Desengano (NUNES et al., 2015). The Serra Serrana have, usually, thin and much leached soils (Cambisols and Red-Yellow Oxisols alic) - (SANTOS et al., 2001). This is due to a humid climate and the interaction mountain chain with frontal systems operating in SRJ (ANDRÉ et al., 20008). Thus, Serrana's slopes, particularly the Serra da Bocaína and Serra dos Órgãos, record rainfall $2000 \mathrm{~mm}_{\text {year }}{ }^{-1}$. Only the Serra das Araras and Serra do Imbé more lowered and indented have rainfall lower than $1500 \mathrm{~mm}$ year $^{-1}$ and less leachate soils (SANTOS et al., 2001).
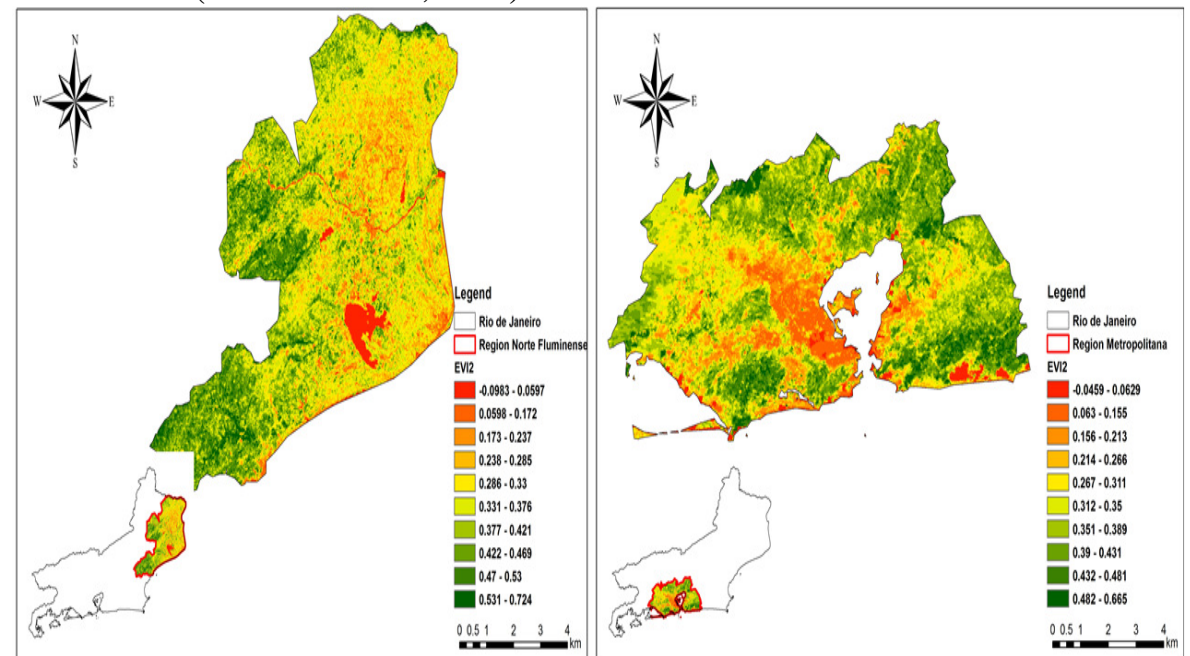

Figure 3. EVI2 indices from Norte Fluminense (left) in October 2003 and from Metropolitana (right) in October 2005.
Spatial analysis of EVI2 in Norte Fluminense region showed an NS vegetation growth in October 2003, at directions W-NW, SW and W-SW from 0.377 to 0.724 (Figure 3). Large areas without vegetation were observed at directions SW and E-NE of the region, and wetlands (water bodies) such as Lagoa Feia at SE, Lagoa de Cima at NW and Lagoa Completa at E-NE and Rio Paraíba do Sul basin, which crosses the region (Figure 3 ). According to Marengo and Alves (2005), despite the region has low rainfall rates $\left(1000 \mathrm{~mm} \mathrm{ano}^{-1}\right)$ and high temperatures with maximum average $\left(32^{\circ} \mathrm{C}\right.$ to $\left.34^{\circ} \mathrm{C}\right)$, it has been suffering in the last decades with the land use and occupation through sugarcane and petroleum activities that have led the Norte Fluminense region to a marked environmental degradation. 
EVI2 map from Metropolitana region (RMRJ) showed the occurrence of abrupt changes in vegetation in October 2005, with a NS vegetation growth, from 0.312 to 0.665 , at directions NW, E-NW, E-SE and S$\mathrm{SW}$. A large area without vegetation at $\mathrm{W}$ of RMRJ was observed with EVI2 values (0.063 to 0.311 ). Wide areas with water bodies and sand were observed at directions S, E and W (Figure 3). RMRJ concentrates $70 \%$ of the state economy and $8.04 \%$ of all service properties produced in the country. This region is the second largest Brazilian industrial center, and therefore, it is a region with high land use and occupation and densely populated (ZERI et al., 2011).

EVI2 map from Baixadas Litorâneas region indicates abrupt change in vegetation in May 2011, with insignificant decreasing vegetation, whose EVI2 values were from 0.39 to 0.76 . However, the presence of areas with vegetation ( 0.435 to 0.764$)$ is observed in the entire region. Several water bodies (Lagoas de Maricá, Barra, Guarapina, Jaconé, Saquarema, Jacarepi, Araruama and Justurnaíba) and an extensive sand strip (Arraial do Cabo, Cabo Frio, Armação dos Búzios and Praia das Ostras) were observed at directions S, SE, SW and E.

In Noroeste Fluminense region, EVI2 map showed a decreasing vegetation in April 2006. Extensive areas with vegetation in advanced stage of succession and degradation through EVI2 index and water bodies were observed (Rios Paraíba do Sul, Muriaé, Carangola and Pomba basins) at directions NW, N, E, SE, S-SW and W-SW.
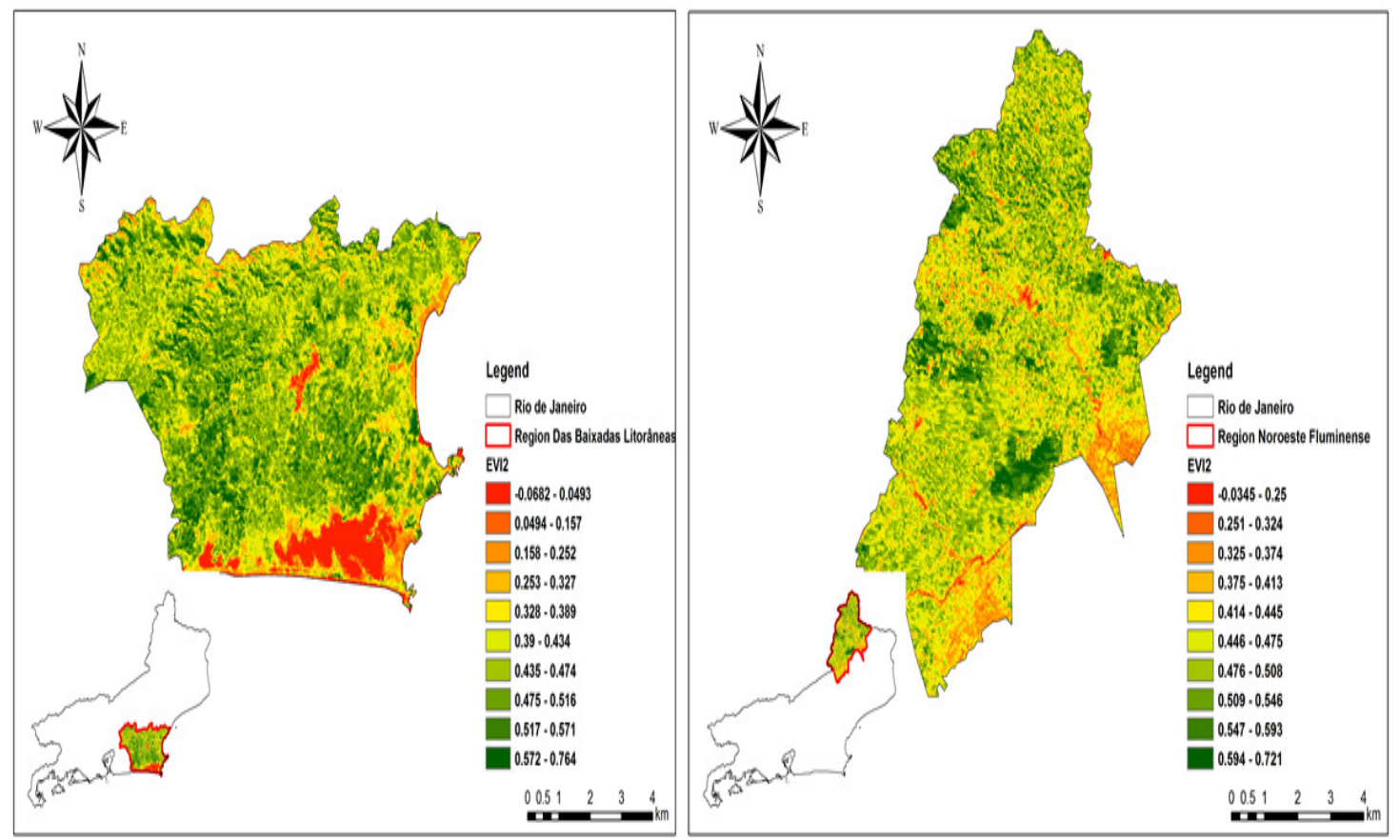

Figure 4. EVI2 indices from Baixadas Litorâneas (left) in May 2011 and from Noroeste (right) in April 2006.

EVI2 thematic map from Costa Verde region showed a decreasing vegetation in May 2004, whose EVI2 values were from 0.446 to 0.475 . In this region, there is a wide degraded area and phenological variation at portions $\mathrm{N}, \mathrm{E}$ and $\mathrm{S}$. The presence of wetlands was identified by EVI2 (-0.0715 -0.0841) across the area of the region's coast. EVI2 map from Centro Sul Fluminense indicated an abrupt change in decreasing the vegetation. Wetlands (water bodies) occurred in the portions $\mathrm{W}$ and S, with EVI2 values (-0.0715 -0.0841). Lastly, vegetation growth areas $(0.461-0.49)$ were observed at portions $\mathrm{W}$ and $\mathrm{E}-\mathrm{NE}$ of the region.

Simulation analysis of the regions Média Paraíba - (MP), Serrana - (SE) and Norte Fluminense -
(NF) for future scenarios of changes in vegetation trend indicated a high similarity in the decreasing vegetation. According to the conditional probability, via Markov chain, the probability of change for the MP scenario $(0.00455 \%)$ and SE $(0.00413 \%)$ from 1 to 2 years and $0.00412 \%$ and from 3 to 10 years, respectively. NF scenario was used for generating the first transition matrix. The obtained percentages represent a change in vegetation trend. Government regions SE, Metropolitana (ME) and NF again showed a decreasing vegetation in the probability of change for the SE $(0.003254 \%)$ and ME $(0.003222 \%)$ from 1 to 2 years and varied $0.003223 \%$ constantly in the range 3 to 10 years, respectively (Figure 6). 

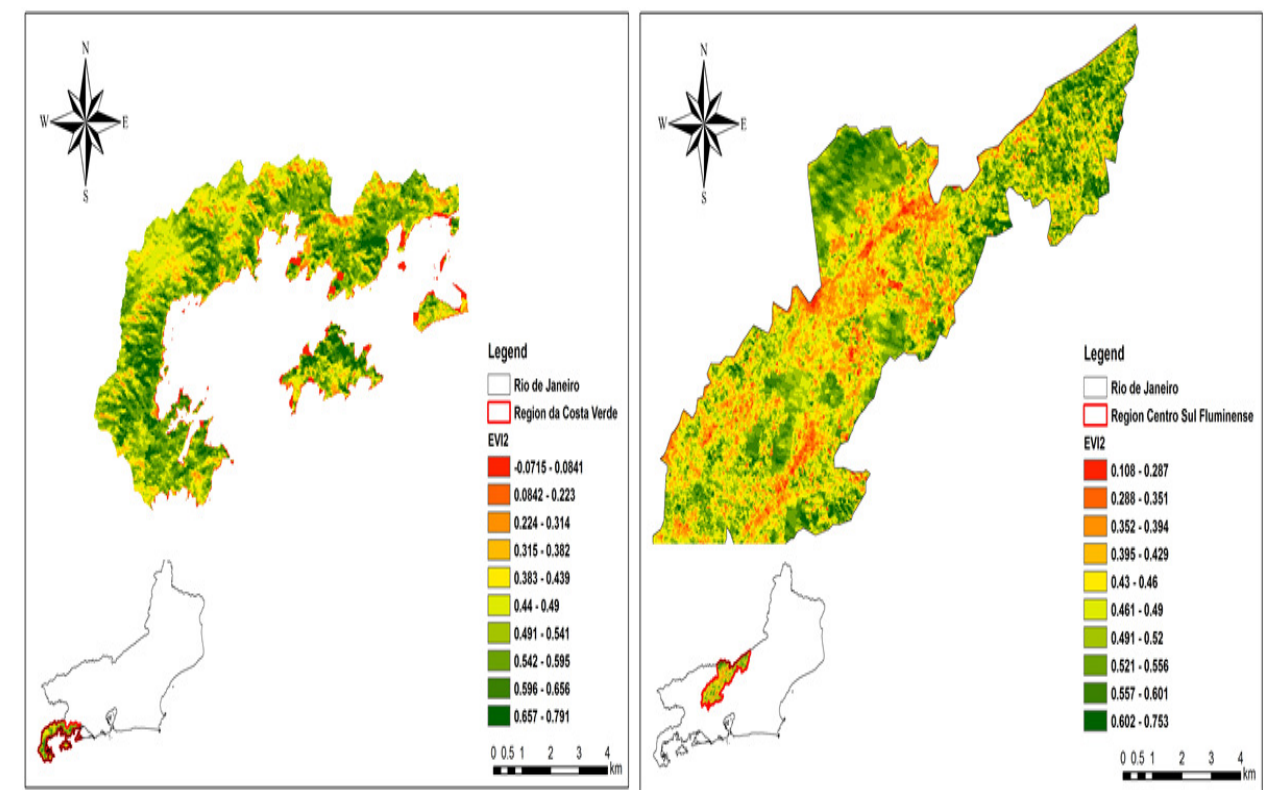

Figure 5. EVI2 indices from Costa Verde (left) in May 2004 and EVI2 from Centro Sul Fluminense (right) in April 2006.
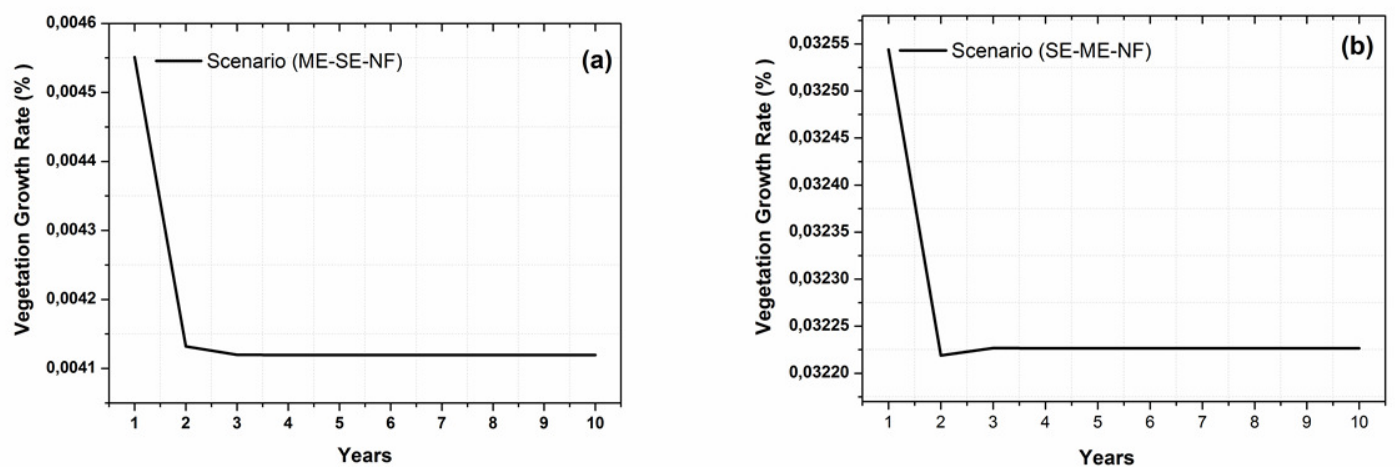

Figure 6. Future change scenarios $(\mathrm{MP}-\mathrm{SE})-(\mathbf{a})$ and $(\mathrm{SE}-\mathrm{ME})-(\mathbf{b})$ in the vegetation trend at scales from 1 to 10 years for the Government regions Médio Paraíba (MP), Serrana (SE), Serrana (SE) and Metropolitana (ME).

Future scenarios show changes in the vegetation trend for the regions NF, ME and MP, now an decreasing vegetation, now an vegetation growth according to the probability of change for $\mathrm{NF}-\mathrm{ME}$ $(0.01896 \%, 0.01881 \%)$ and NF - MP $(0.01851 \%$, $0.01872 \%$ ) for the range 1 to 2 years and constantly ranged from $0.01881 \%$ to $0.01872 \%$ from 3 to 10 years. Transition matrices used were the future scenarios MP and SE (Figure 7). Changes in values of vegetation trends were for the scenario $\mathrm{NF}-\mathrm{ME}$ in decreasing (0.0000003792 and 0.0000003762), followed by scenario NF - MP $(0.0000025907,0.0000026211$ and 0.0000026207 ) in increasing, respectively.

Simulations for future change scenarios $(\mathrm{BL}-$ $\mathrm{CS}-10),(\mathrm{CS}-\mathrm{BL}-10),(\mathrm{NO}-\mathrm{CV}-10)$ and $(\mathrm{CV}-$ $\mathrm{NO}-10)$ in vegetation trend show, in a general manner, a similarity as the changes occurring in the vegetation trend in the Government regions Baixadas Litorâneas (BL), Costa Verde (CV) and NF. In the respective future scenarios were observed a high decreasing and growth according to the Markov chain, the probability of changes in the trend for the scenario BL - CS $(0.118 \%$ to $0.066 \%)$ and for the scenario CS - BL $(0.069 \%$ to $0.115 \%$ ) - (Figure 8). However, it is noted constantvalues of change probabilities $(0.063 \%$ e $0.111 \%)$ at range 3 to 10 in the respective scenarios. The values of changes in decreasing vegetation trends, for the scenario BL - CS (0.000047; 0.000026 and 0.000025), followed by scenario CS - BL (0.000023; 0.000045 and $0.000044)$. A unitary matrix was used to perform the interaction between future scenarios. 

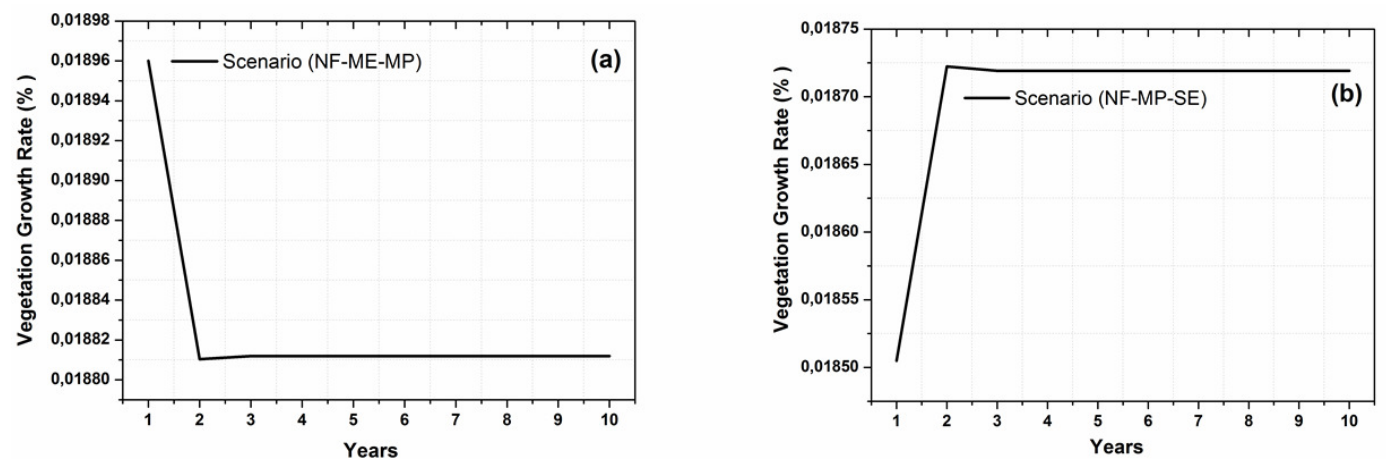

Figure 7. Future change scenarios $(\mathrm{NF}-\mathrm{ME}-\mathrm{MP})-(\mathbf{a})$ and $(\mathrm{NF}-\mathrm{MP}-\mathrm{SE})-(\mathbf{b})$ in the vegetation trend at scale from 1 to 10 years for the Government regions Norte Fluminense (NF), Metropolitana (ME) and Serrana (SE).
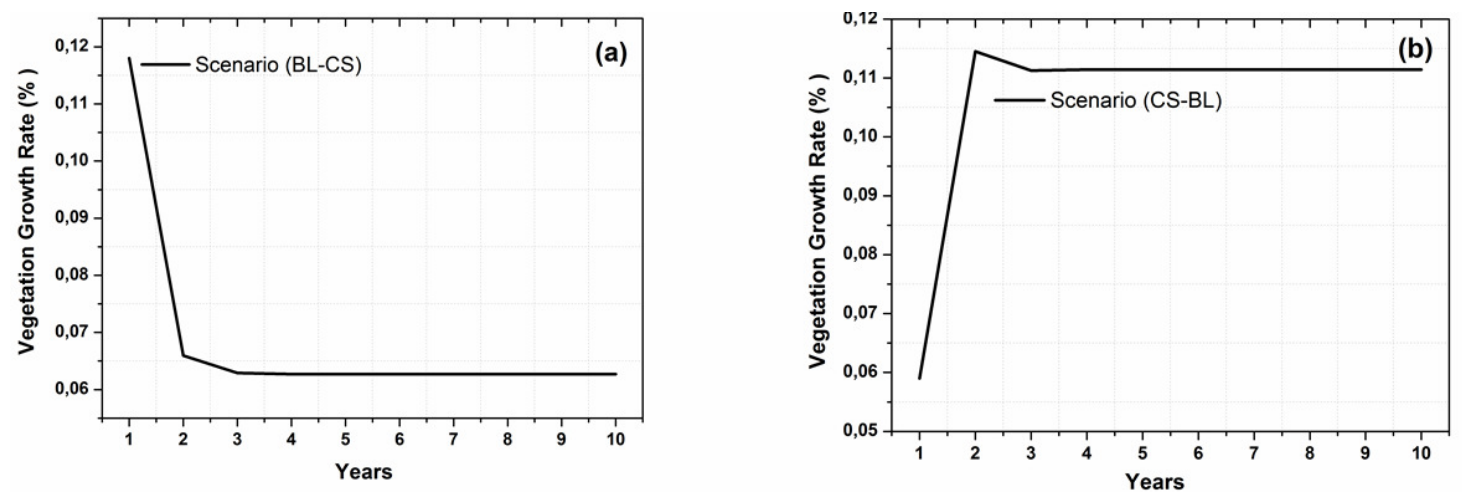

Figure 8. Future change scenarios $(B L-C S)-(\mathbf{a})$ and $(C S-B L)-(b)$ in vegetation trende at scale from 1 to 10 years for the Government regions Baixadas Litorâneas (BL) and Centro Sul Fluminense (CS).

In the future scenarios $\mathrm{NO}-\mathrm{CV}-10$ and $\mathrm{CV}-$ $\mathrm{NO}-10$, we observed growth and decreasing trend change probabilities. In the scenario $\mathrm{NO}-\mathrm{CV}$ was observed the growth percentage values $0.035 \%$ to $0.081 \%$, followed by scenario CV - NO () with percentage values of decreasing from $0.083 \%$ to $0.039 \%$. We noted at scale from 3 to 10 years constant values of vegetation change probabilities of $0.079 \%$ and
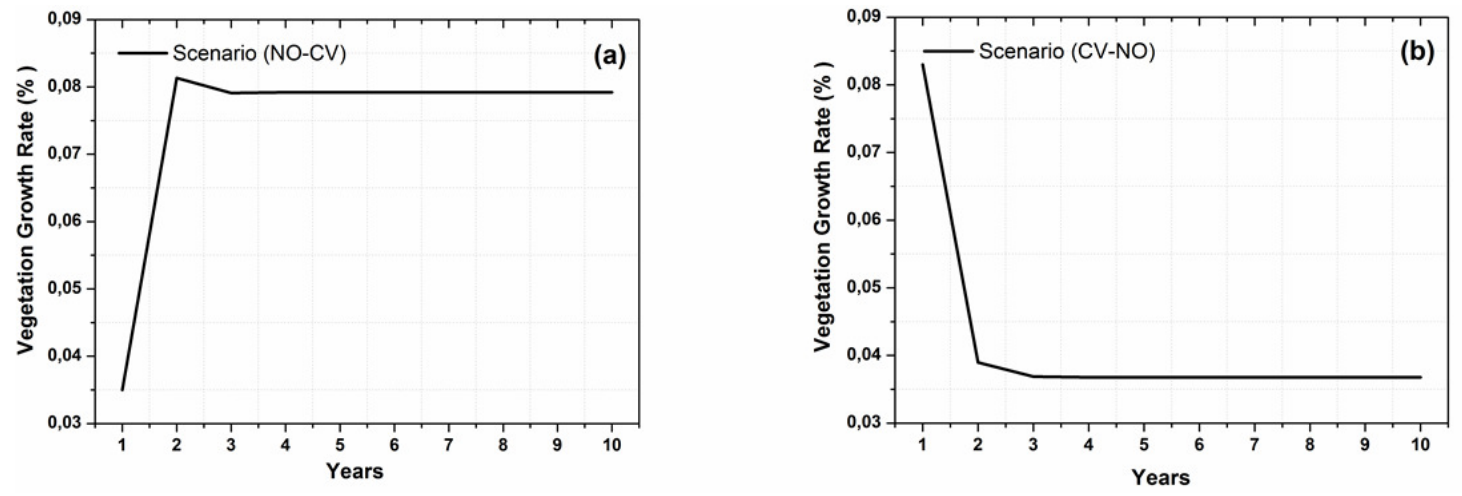

Figure 9. Future change scenarios $(\mathrm{NO}-\mathrm{CV})-(\mathbf{a})$ and $(\mathrm{CV}-\mathrm{NO})-(\mathbf{b})$ in vegetation trend at scale from 1 to 10 years for the Government regions Noroeste Fluminense (NO) and Costa Verde (CV). 


\section{CONCLUSIONS}

Mann-Kendall test aplied to EVI2 index detected changes in vegetation in the state of Rio de Janeiro. Insignificant trends of vegetation growth in the regions Médio Paraíba, Serrana, Noroeste Fluminense and Metropolitana. . Insignificant trends of decreasing vegetation in the Norte Fluminense and Costa Verde and, at last, significant trends of decreasing vegetation recorded in Baixadas Litorâneas and Centro Sul Fluminense.
Pettitt's test identified no significant abrupt changes in growth and decreasing vegetation in six Government regions (Médio Paraíba, Serrana, Norte Fluminense, Metropolitana, Noroeste Fluminense andCosta Verde) and significant abrupt changes in growth and decreasing vegetation in Baixadas Litorâneas and Centro Sul Fluminense.

Markov chain applied for the future change scenarios in vegetation trend in the State of Rio de Janeiro show a strong similarity in the growth and decreasing vegetation.

RESUMO: O estudo teve como objetivo avaliar o crescimento e a diminuição da tendência de vegetação por Indice de Vegetação Aprimorado 2 (EVI 2) e com a aplicação de testes estatísticos e cadeia de Markov no estado do Rio de Janeiro (ERJ). Dados mensais do índice Enhanced Vegetation Index (EVI2) foram calculados para vegetação do Estado do Rio de Janeiro (ERJ) entre 2001 a 2012. A tendência do EVI2 foi avaliada pelos testes Mann-Kendall (MK), Pettitt (P) e Estimador da Inclinação da Curvatura Sen $\left(S_{e}\right)$, enquanto os cenários futuros pela Cadeia de Markov. De um modo geral, há uma tendência insignificante de crescimento da vegetação em $75 \%$, seguido de uma tendência significativa de diminuição em $25 \%$ das regiões de Governo. O teste de Pettitt mostrou a existência de mudanças bruscas não significativas (NS), ambos de crescimento e diminuição da vegetação em seis regiões de Governo e significativas (S) de diminuição da vegetação nas demais. Análise espacial do EVI2 nas regiões do Médio Paraíba e Serrana mostrou a ocorrência NS de mudança brusca da vegetação em novembro de 2007 e 2003 . As regiões Norte Fluminense e Metropolitana mostraram um crescimento NS na vegetação em outubro de 2003 e 2005. As regiões Noroeste Fluminense e Centro Sul Fluminense revelaram uma mudança brusca de diminuição da vegetação NS e S em de abril de 2006 . As regiões Costa Verde e das Baixadas Litorâneas observaram-se mudanças bruscas S e NS de diminuição da vegetação em maio de 2004. Os cenários futuros constataram mudanças na tendência da vegetação no ERJ com indicação de diminuição. Os prognósticos de mudanças dos cenários futuros com variação de 1 a 2 anos em intervalos constante (3 a 10 anos) foram observados, em todos os cenários futuros analisados no ERJ.

PALAVRAS-CHAVE: Sensores orbitais. Testes estatísticos. Geotecnologia. Matriz markoviana.

\section{REFERENCES}

ANDRÉ, R. G. B.; MARQUES, V. S.; PINHEIRO, F. M. A; FERRAUDO, A. S. Identificação de regiões pluviometricamente homogêneas no estado do Rio de Janeiro, utilizando-se valores mensais. Revista Brasileira de Meteorologia, São José dos Campos, v. 23, n.4, p.501-509, 2008.

ALEIXO, A.; ALBERNAZ, A. L.; GRELLE, C. E. V.; VALE, M. M.; RANGEL, T. F. Mudanças Climáticas e a Biodiversidade dos Biomas Brasileiros: Passado, Presente e Futuro. Natureza e Conservação, Goiânia, v. 8, n. 2, p. 194-196, 2010. http://dx.doi.org/10.4322/natcon.00802016

CAÚLA, R. H.; OLIVEIRA-JÚNIOR, J. F.; LYRA, G. B.; DELGADO, R. C.; HEILBRON FILHO, P. F. L. Overview of fire foci causes and locations in Brazil based on meteorological satellite data from 1998 to 2011. Environmental Earth Sciences, Melbourne, v. 74, n. 2, p. 1497-1508, 2015. http://dx.doi.org/10.1007/s12665$015-4142-\mathrm{z}$

DELGADO, R. C.; OLIVEIRA-JÚNIOR, J. F.; CHAGAS, M. C.; GOIS, G.; SANTOS, R. S.; TEODORO, P. E. Space-time variability of vegetation by orbital platforms in the western Amazon. Bioscience Journal, Uberlândia, v. 31, n. 6, p. 1844-1851, 2015. http://dx.doi.org/10.14393/BJ-v31n6a2015-29219

DEMARCHI, J. C.; PIROLI, E. L.; ZIMBACK, C. R. L. Análise temporal do uso do solo e comparação entre os índices de vegetação NDVI e SAVI no município de Santa Cruz do Rio Pardo - SP usando imagens Landsat5. Ra'e ga, Curitiba, v. 21, p. 234-271, 2011. 
FERNANDES, M. C.; COURA, P. H. F.; Sousa, G.M.; AVELAR, A.S. Avaliação Geoecológica de Susceptibilidade à Ocorrência de Incêndios no Estado do Rio de Janeiro, Brasil. Floresta e Ambiente, Seropédica, v. 18, p. 299-309, 2011.

GOULART, A. C. O.; DELGADO, R. C.; OLIVEIRA JÚNIOR, J. F.; GOIS, G.; OLIVEIRA, E. S. Relação espectro-temporal entre índices de vegetação e a chuva na cidade do Rio de Janeiro. Revista de Ciências Agrárias, Belém, v. 58, n. 3, p. 277-283, 2015. http://dx.doi.org/10.4322/rca.1990

HUETE, A. R.; LIU, H. Q.; BATCHILY, K.; VAN LEEUWEN, W. J. D. A comparison of vegetation indices over a global set of TM images for EOS-MODIS. Remote Sensing of Environment, Salt Lake City, v. 59, p. 440-451, 1997. http://dx.doi.org/10.1016/S0034-4257(96)00112-5

HUETE, A. R.; JUSTICE, C.; LEEUWEN, W. V. MODIS vegetation index (MOD13) Algorithm theoretical basis Document Version 3, NASA Goddard Space Flight Center: Maryland. 1999, 122p.

HUETE A, A.; DIDAN, K.; MIURA, T.; RODRIGUEZ, E. P.; GAO, X.; FERREIRA, L. G. Overview of the radiometric and biophysical performance of the MODIS vegetation indices. Remote Sensing of Environment, Salt Lake City, n. 83, p. 195-213, 2002.

JIANG, L.-Q.; CAI, R; WANNINKHOF, Y; WANG, H.; LU, G. E. R. Air-sea CO2 fluxes on the U.S. South Atlantic Bight: spatial and seasonal variability. Journal of Geophysical Research, v. 113, p. 256-267, 2008. http://dx.doi.org/10.1029/2007JC004366

MARENGO J. A.; ALVES, A. M. Tendências hidrológicas da bacia do rio Paraíba do Sul. Revista Brasileira de Meteorologia, São José dos Campos, v. 20, n. 2, p. 215-226, 2005.

NUNES, M. T. O.; SOUSA, G. M.; TOMZHINSKI, G.W.; OLIVEIRA-JÚNIOR, J. F.; FERNANDES, M. C. Factors Influencing on Susceptibility Forestry Fire in Itatiaia National Park. Anuário do Instituto de Geociências, Rio de Janeiro, v. 38_1, p. 54-62, 2015.

PEDROSA, B. M. \& CÂMARA, G. Modelagem dinâmica e sistemas de informações geográficas. In: MEIRELLES, M. S. P.; CÂMARA, G. \& ALMEIDA, C. M. Geomática: Modelos e aplicações ambientais. Brasília, Embrapa, 2007. p.235-280.

ROUSE J. W.; HAAS R. H., SCHELL J. A.; DEERING D.W. Monitoring vegetation systems in the Great Plains with ERTS. In: Fraden S.C., Marcanti E.P. \& Becker M.A. (eds.), Third ERTS-1 Symposium. Washington, pp. 309-317, 1974.

R Development Core Team (2011) R: A language and environment for statistical computing. R Foundation for Statistical Computing, Vienna, Austria. ISBN 3-900051-07-0, URL: http://www.R-project.org/

SANTOS, J. E.; NOGUEIRA, F.; PIRES, J.S.R.; OBARA, A.T. E PIRES, A.M.Z.C.R. The value of the Ecological Station of Jatai's ecosystem services and natural capital. Revista Brasileira de Biologia, São Carlos, v. 61, n. 2, p. 171 190, 2001.

SNEYERS, R. Sur l'analyse statistique des series dóbservations. Gênevè: Organisation Méteorologique Mondial, 1975. (OMN, Note technique, 143).

TEIXEIRA, L. M.; CHAMBERS, J. Q.; SILVA, A. R.; LIMA, A. J. N.; CARNEIRO, V. M. C.; SANTOS, J.; HIGUCHI, N. Projeção da dinâmica da floresta natural de terra-firme, região de Manaus-AM, com o uso da cadeia de transição probabilística de Markov. Acta Amazonica, Manaus, v. 37, n. 3, p. 377 - 384, 2007. http://dx.doi.org/10.1590/S0044-59672007000300009 
YANG, X.; ZHENG, X. Q.; LV, L. N. A Spatiotemporal model of land use change based on ant colony optimization, Markov chain and cellular automata. Ecological Modelling, Halifax, v.233, p. 11-19, 2012. http://dx.doi.org/10.1016/j.ecolmodel.2012.03.011

ZERI, M.; OLIVEIRA-JÚNIOR, J. F.; LYRA, G. B. Spatiotemporal analysis of particulate matter, sulfur dioxideand carbon monoxide concentrations over the city of Rio de Janeiro, Brazil. Meteorology and Atmospheric Physics, Viena, v. 113, n. 1, p. 139-152, 2011.

ZHANG, Y.; XU, M.; CHEN, H.; ADAMS, J. Global pattern of NPP to GPP ratio derived from MODIS data: effects of ecosystem type, geographical location and climate. Global Ecology and Biogeography, Malden, v. 18, n. 3, p. 280-290, 2009. http://dx.doi.org/10.1111/j.1466-8238.2008.00442.x 